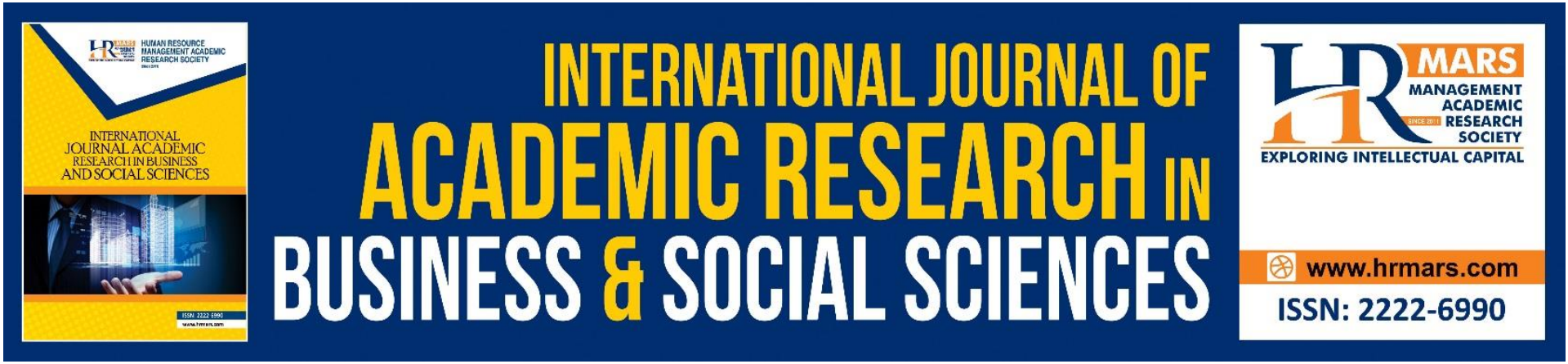

\title{
The Relationship between Marketing Management Capabilities and SMEs Business Performance during COVID- 19 Pandemic
}

Haslenna Hamdan, Zalinawati Abdullah, Wan Maziah Wan Ab Razak, Nurul Ulfa Abdul Aziz, Ken Sudarti

To Link this Article: http://dx.doi.org/10.6007/IJARBSS/v11-i18/11434 DOI:10.6007/IJARBSS/v11-i18/11434

Received: 05 August 2021, Revised: 29 August 2021, Accepted: 20 September 2021

Published Online: 08 October 2021

In-Text Citation: (Hamdan et al., 2021)

To Cite this Article: Hamdan, H., Abdullah, Z., Razak, W. M. W. A., Aziz, N. U. A., \& Sudarti, K. (2021). The Relationship between Marketing Management Capabilities and SMEs Business Performance during COVID19 Pandemic. International Journal of Academic Research in Business and Social Sciences, 11(18), 160-178.

Copyright: () 2021 The Author(s)

Published by Human Resource Management Academic Research Society (www.hrmars.com)

This article is published under the Creative Commons Attribution (CC BY 4.0) license. Anyone may reproduce, distribute, translate and create derivative works of this article (for both commercial and non-commercial purposes), subject to full attribution to the original publication and authors. The full terms of this license may be seen at: http://creativecommons.org/licences/by/4.0/legalcode

Special Issue Title: TiBECVII 2021, 2021, Pg. 160 - 178

http://hrmars.com/index.php/pages/detail/IJARBSS

JOURNAL HOMEPAGE

Full Terms \& Conditions of access and use can be found at http://hrmars.com/index.php/pages/detail/publication-ethics 


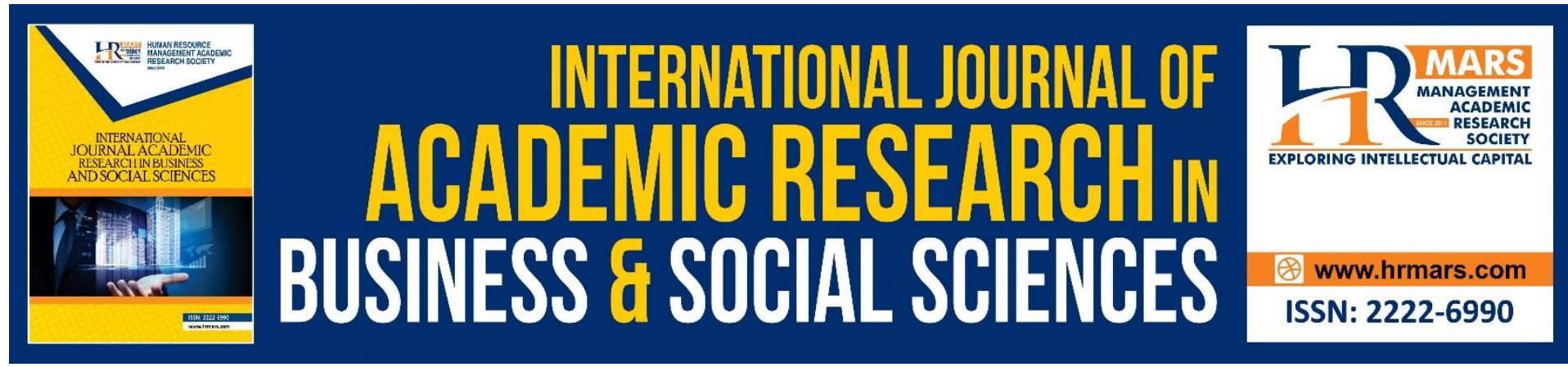

\title{
The Relationship between Marketing Management Capabilities and SMEs Business Performance during COVID-19 Pandemic
}

\author{
Haslenna Hamdan ${ }^{1}$, Zalinawati Abdullah ${ }^{1}$, Wan Maziah Wan Ab \\ Razak $^{1}$, Nurul Ulfa Abdul Aziz ${ }^{1}$, Ken Sudarti \\ ${ }^{1}$ Fakulti Pengurusan dan Perniagaan, UiTM Cawangan Terengganu, 23000 Dungun, \\ Terengganu, Malaysia, ${ }^{2}$ Fakultas Ekonomi, Universitas Islam Sultan Agung, Semarang, \\ Indonesia \\ Email: has@uitm.edu.my,zalin5026@uitm.edu.my
}

\begin{abstract}
COVID-19 pandemic has created a new norm for SMEs business operations in the fashion industry, despite the disruptions to the world economy and mankind. In view of these changes, it is imperative for SMEs to prioritise their marketing management capabilities in order to improve their business performance. This study upholds the theoretical lens of resource-based view theory. This study examines the relationship between marketing management capabilities and SMEs business performance using SPSS statistical package consuming minimum data of selected 283 SMEs that are involved in the fashion industry from three (3) states in East Coast Malaysia. The results of this study provide important information for SMEs to make better informed decisions in developing the right combination of marketing planning and marketing implementation capabilities to improve their business performance. Further research should also seek to synthesise findings of the above major theoretical frameworks in the context of marketing management capabilities dimensions and business performance of SMEs. The originality of this study lies in learning the geographical impacts of SMEs in the new norm of COVID-19 and challenging the applicability of the resource-based view arguments in this specific context.

Keywords: Business Performance, Marketing Management Capabilities, Marketing Planning, Marketing Implementation, SMEs
\end{abstract}

\section{Introduction}

SMEs play a significant role and are one of the drivers in boosting Malaysia's economic development. In Malaysia, value-added for SMEs plays an important role in maintaining favourable economic performance, in which SMEs account for $97.3 \%$ of the total industry in the country (SME Annual Report, 2019). SMEs are seeking marketing management capabilities that will enable them to increase their business performance not only for the local market but also for the international market. The global problem of COVID-19 is seen to have major impacts on various industries and is transforming new global trends (e.g publication industry, travel and tourism industry, apparel and clothing industry) (Bhatti et al., 2020; Phan 
et al., 2020). McKinsey (2020) predicted the global fashion sales will decline by only 0 to 5 percent in 2021 and is anticipated to increase quickly in the third quarter of 2022; if the COVID-19 virus can be quickly overcome in different geographic locations. However, if the COVID-19 virus is still prevalent worldwide, global fashion sales will drop by 10 to 15 percent and are estimated to rise in the fourth quarter of 2023 (McKinsey, 2020). COVID-19 pandemic has caused a global economy slowdown; and consequently, affecting the global fashion industry to decline rapidly from $\$ 35.8$ billion in 2019 to $\$ 31.4$ billion in 2020 at a compound annual growth rate (CAGR) in which decreasing at 12.32 percent (McKinsey, 2020). Meanwhile, the fashion industry is expected to recover by reaching $\$ 38.1$ billion in 2023, with a CAGR rate of 6.7 percent (McKinsey, 2020). As a result of this rapid change in the fashion industry, SMEs need to gauge the latest trends to ensure that their business performance keeps improving not only in the local market but also in the international market.

On a brighter side, COVID-19 has influenced the lifestyle of consumers around the world to buy products through an online platform. Thus, contributes to SMEs marketing management capabilities for both local and international markets. According to Bhatti et al (2020), 36 percent of consumers are reluctant to shop at brick and mortar outlets until they receive the coronavirus vaccine; and 52 percent of consumers avoid shopping at crowded areas. Although the trend for online purchases increased by 6 to 10 percent across product categories, the average online monthly purchases for fashion and accessories per shopper has decreased by 43 percent (UNCTAD, 2020). To date, very few empirical studies have been conducted in examining the relationship between marketing management capabilities and geographical marketing segmentation with business performance; especially on SMEs that are involved in the fashion industry. Barney (1991) conducted a study on marketing management capabilities using a theoretical perspective of resource-based view (RBV) in predicting SMEs business performance in the fashion industry; thus, helps to address both of the above gaps. Based on the RBV theory, the objectives of this study are: 1) to examine the relationship between marketing management capabilities (marketing planning and marketing implementation) and business performance among SMEs in the fashion industry, and 2) to examine the significance difference between geographical marketing segmentation and business performance among Malaysian SMEs in the fashion industry.

This study provides significant contributions to both theory and practice in the field of marketing. The findings present a noticeable pattern regarding the stability and relative importance of marketing management capabilities that consist of marketing planning and marketing implementation on business performance. Furthermore, this study highlighted important insight on the different impact of geographical marketing segmentation in influencing SMEs business performance. Theoretically, this study enhances the understanding of marketing management capabilities on SMEs business performance; and practically, the findings will provide guidelines to assist SMEs owners and policy makers to improve their marketing management capabilities in gaining sustainable competitive advantage.

\section{Literature Review}

\section{Overview of Fashion Industry}

Worldwide, the fashion industry reflects a huge economic contribution where a global trade of 1.3 trillion dollars has been transacted and giving employment to more than 300 million people (Gazzola, 2020; BCG, 2019). According to the market analysis provided by some of the 
main international consultancy companies (McKinsey, 2020; Deloitte, 2020; BCG, 2019), fashion companies today are operating in a very dynamic competitive environment, dominated by the existence of global brands. The fashion industry has been described as uncertain, challenging and disruptive. Due to COVID-19 pandemic, McKinsey (2020) expects a large number of global fashion companies will go bankrupt in the next 12 to 18 months. The McKinsey Global Fashion Index (MGFI) predicted that global fashion industry growth will continue to slow down to 3 to 4 percent slightly below the forecast growth for 2019 which is 3.5 to 4.5 percent (McKinsey, 2020). This is reflected in the performance of 56 percent of global fashion companies that were not earning their capital costs in 2018 and global fashion's profit is expected to fall by 93 percent in 2020 (McKinsey, 2020). This global disruption will create enormous business operations transformations for fashion companies in order to remain resilient in the fashion industry. Established fashion brands and retailers will face growing competition from Asian markets as manufacturers and SMEs step out of their traditional roles and sell directly to global consumers (Gazzola, 2020). It is somewhat plausible to predict the upcoming transitions on consumer behaviour trends in the fashion industry in Europe during the time of a pandemic (Anh, 2021). For fashion companies, there will be continuous applications of sustainable approaches in their manufacturing process and marketing strategy. As consumers and customers being the centre of any business model (Dellaert, 2018), the fact that consumers in Europe are more environmentally conscious and more selective towards fashion choices will exceptionally impact the future of the textile sector, which can be an increase in sustainable business models and marketing models.

Despite the outbreak of COVID-19, rapid increase in interest and demand for millennials and modest fashion markets provide new opportunities for entrepreneurs in the fashion industry. Global spending on clothing are worth \$2.5 trillion; in which \$283 billion (11 percent) spending are made by 1.8 billion Muslim consumers around the world (GIER, 2020). Global Islamic Economy Report (GIER) 2019/20 reported Muslim consumer spending on apparel and footwear is projected to grow to $\$ 402$ billion by 2024 . Apparently, Muslim consumers is resonating with Muslim millennials; hence, general awareness of modest fashion is increasing rapidly. Many mainstream brands have launched modest fashion lines, such as Japan's Uniqlo hijab line and Nike's Pro Hijab sportswear to cater for this new young segment. This huge predicted growth signifies great potential for modest fashion to stand out in the global apparel market.

\section{Business Performance}

Business performance is a combination of outcomes from business activities perceived by the owner or manager of the company related to sales revenue growth, increase in customer volume, expansion of sales territory, increased profitability and capital growth of SMEs' efforts (Morgan, 2012; Taleghani et. al., 2011). The COVID-19 pandemic is a health crisis, putting firms around the world becoming out of balance (Razak et al., 2020). Accordingly, responding to the pandemic has gauged the need for SMEs to accelerate the adoption of agile ways of working and develop new business model transformations to help outmanoeuvre uncertainty with good marketing management capabilities. Business owners measure business performance to track company goals and targets; investors use business performance to measure specific financial and productivity indicators; management uses business performance to analyse past performance and make necessary adjustments in the future; and workers use business performance to track productivity in an effort to find 
payment bonus criteria (Lee et. al., 2015). Some researchers use growth dimensions to measure business performance (Cho and Pucik, 2005; Debicki, 2017; Gao et al., 2007; Morgan et al., 2009). This dimension may be more accurate for SME-level companies (Wiklund and Shepherd, 2005). For meta-analysis of the study, Stam et al (2014) describe three dimensions to measure business performance; namely (a) performance improvement, such as sales, profits, employment, and market share; (b) profits such as asset returns, equity returns, and sales returns; and (c) non-financial achievements such as technical excellence, competitive ability, productivity, and export performance. The importance of SMEs planning to manage resources during growth have been highlighted in previous study (Richbell et al., 2006; Robert, 2013; Mazzarol et al., 2009). Owners who develop the most profitable businesses seem to be those who are prepared to grow their businesses at a steady, unspectacular rate over a relatively long period, reflecting the work of Davidsson et al (2009) while younger businesses were more likely to be profitable. The model on employment growth displayed the highest level of statistical significance. These findings contribute to more critical studies that have stressed the discontinuous, sporadic nature of growth (Blackburn et al., 2009; Storey, 2011), and by complementing the work of St-Jean et al. (2008), who highlight how the difficulties of managing internal change can impede growth. Business performance used in this study follows the above-mentioned dimensions and the ability of the respondents to answer correctly based on the data and knowledge that they have.

\section{Marketing Management Capabilities}

The marketing management capabilities are based on a well-performed marketing management process that consists of analysing market opportunities, formulating clear marketing objectives, and developing a marketing strategy that should be implemented and controlled (Kotler, 2004). The study by Takata (2016) examined the effects of industry forces, market orientation, and marketing capabilities on business performance from Japanese manufacturers from 2009 until 2011. The finding revealed that marketing capabilities positively influence business performance. In addition, marketing capabilities are the most significant factor on business performance compared with industry forces and market orientation. This result was consistent with previous studies done by Day (1994); Jaakkola et al., (2010); Krasnikov and Jayachandran's (2008); Morgan et al., (2009) and Ngo and O'Cass (2012). Thus, widespread coronavirus worldwide has indeed triggered the re-evaluation of marketing planning and marketing implementation by SMEs during this pandemic. The higher the management capabilities of the SMEs owners, the easier it will be in formulating a business strategy (low-cost strategy and differentiation strategy) to improve the performance of SMEs. SMEs that are oriented towards continuous innovation will be able to create new products, which is an advantage for SMEs to lead the market because they have something unique that other companies do not have, which ultimately improves the performance of SMEs (Hendra et al., 2021).

\section{Marketing Planning Capabilities}

Marketing management capabilities are the ability of a firm to respond and adapt to the changing market environments in order to ensure that resources are used in line with the company's environment while at the same time to attain the company's financial objectives (Slotegraaf and Dickson, 2004). Not only Krasnikov et al., (2009) found that marketing planning capabilities will lead to better business performance but Vorhis et al., (2009) concluded that marketing planning capabilities are influenced by organizations business 
strategies. Referring to the relationship between marketing planning capabilities and business performance, most of the studies revealed that marketing planning capabilities have a positive effect on a firm's performance (Chang et al., 2010; Morgan et al., 2009; Slotegraaf \& Dickson, 2004; Vorhies and Morgan, 2005).

The difficulty of finding a strong positive impact of marketing planning on performance is paradoxical and the technology of marketing planning such as engaging in situation analysis, critically evaluating the environment faced and the organisation's internal capabilities, generating strategies and options, evaluating each potential strategy in terms of their appropriateness for the situation, is intuitively appealing. It is expected a firm approaching its strategic decisions using the best mix of features from synoptic and incremental planning processes to achieve improved performance (Pulendran et al., 2003). Marketing planning quality was a significant predictor of market orientation and further evidence of the significant relationship between market orientation and business performance should give a strong message to organisations (Pulendran et al., 2003).

\section{Marketing Implementation Capabilities}

Marketing implementation capabilities is a process that carry out plans into actions; therefore, marketing implementation capabilities play a key role in improving firm performance by transforming the marketing strategy plan into action (Kotler \& Keller, 2009). Furthermore, evidence revealed that marketing implementation capabilities positively impact on organizational performance (Vohies and Morgan, 2005; White et al., 2003). As noted above, Salter et al (2010) found that the implementation of marketing capabilities had a positive impact on the firm's performance in manufacturing and service organisations in particular. In addition to Cizmar and Weber (2000) stated that the implementation of marketing capabilities is one of the main factors that affect the marketing effectiveness of the hotel industry, which results in greater hotel performance. The quality of marketing planning is associated with a higher level of market orientation (Pulendran et al., 2003). The research design gives no evidence as to causality, and a case can be made either way. Perhaps betterquality planning assists managers seeking to implement a market orientation to achieve their goal, or conversely, market orientation assists planning by providing a clear and unambiguous goal that serves to focus the planning effort. However, what the research does strongly suggest is the primacy of market orientation over marketing planning in its effect on business performance (Pulendran et al., 2003).

\section{Fashion Industry and Geographical Marketing Segmentation}

The world market shares for the top four exporters of apparel China, the European Union (EU28), Bangladesh, and Vietnam) accounted for around 71.4 percent in 2019, a lower than 74\% from 2016 to 2018 (WTO, 2020). This is primarily due to China's reduced market shares; thus, exporting less apparel and more textiles to the world. China's market shares in world apparel exports fell from its peak of 38.8\% in 2014 to a record low of $30.8 \%$ in 2019 (was $31.3 \%$ in 2018) (WTO, 2020). However, despite the reduction of apparel's market shares, China still accounted for 39.2\% of world textile exports in 2019 (WTO, 2020). It is important to recognize that China is playing an increasingly critical role as a textile supplier for many apparel-exporting countries in Asia. Mckinsey (2020) reported the Indian clothing market worth $\$ 53.7$ billion in 2020, making India the sixth largest globally. Southeast Asia also provides significant opportunities; at nearly 270 million people, Indonesia is the fourth largest country in the world by population. Vietnam and the Philippines are seeing rapid GDP growth. 
Across Southeast Asia, the median age is just 29, against 37 in China, highlighting the potential for growth as large numbers of young people enter the workforce each year. As in China, demand is being driven by digitally native consumers, excited by the possibility of creativity and self-expression. It is worth highlighting that these countries are highly diverse; some consumers, such as in the Philippines, have a high affinity for western fashion trends, while Indonesia is due to be the largest modest fashion market in the world.

Global Muslim spend on modest fashion has increased by 4.8 percent from $\$ 270$ billion to \$283 billion in 2018; ranking Turkey, UAE and Indonesia as the top three countries in spending. Indonesia, as the world's largest Muslim country has 13.1 percent of the total Muslim population in the world; undeniably has an influence on modest fashion development (GIER, 2020). Furthermore, the emergence of Muslim fashion communities in various regions in Indonesia, such as the Hijabers Community and Mom Hijabers (women wearing hijab) has made Indonesia the largest modest fashion business. As such, major fashion retailers and brands can generate substantial revenues by adapting collections as well as launching modest fashion lines.

It is more strenuous for fashion companies to make marketing planning forward due to the interconnected nature of the fashion industry (McKinsey, 2020). In the lens of COVID-19, while China is trying to recover, the contrasting situation has become uncontrollable in European countries and the United States; and certain developing countries have also been severely affected. As some successful fashion players become over reliant on China; while others struggle, fashion companies should deliberately spread their risk by expanding to other high growth geographical segmentation (McKinsey, 2020). A cross-national market segmentation in the fashion industry that segments fashion markets, indicated that global consumer culture is a stronger influence for cross-national differences. Given the strength of the main effects for the fashion segments, Eunju Ko et al (2007) results imply that global fashion marketers should consider the motivations of the segment when trying to appeal across markets. The crisis has emphasised the need to move to more sustainable and responsible ways of working in all areas of the value chain.

\section{Theoretical Framework and Hypotheses Development}

Drawing on the RBV theory proposed by Barney (1991), the literature assumes that a firm with superior marketing management capabilities will achieve superior business performance. It is because the firm can provide its target customers with better value, such as higher quality products, a suitable price setting, better customer services, and additional beneficial information through better marketing mix decisions (Takata, 2016). RBV is a theoretical underpinning to describe the relationship between marketing management capabilities and business performance. As such, RBV is considered as the appropriate theoretical framework to study business performance among SMEs. RBV theory focused on both tangibles and intangibles (Galbreath and Galvin, 2004); and not all resources are equally significant to business performance (Barney, 1991; Galbreath and Galvin, 2004). In fact, the most influential factor for business performance seem to be intangible factors (Barney, 1991; Galbreath and Galvin, 2004). A study by Kristandl and Bontis (2007) defined intangibles as a subset of RBV strategic resources, such as capability. Applying RBV theory in the context of this study, it is proposed that marketing management capabilities that consist of marketing planning and marketing implementation will significantly influence the business performance 
of SMEs in Malaysia. With reference to the RBV theory, the following theoretical framework and hypotheses were proposed for this study:

Marketing Management Capabilities

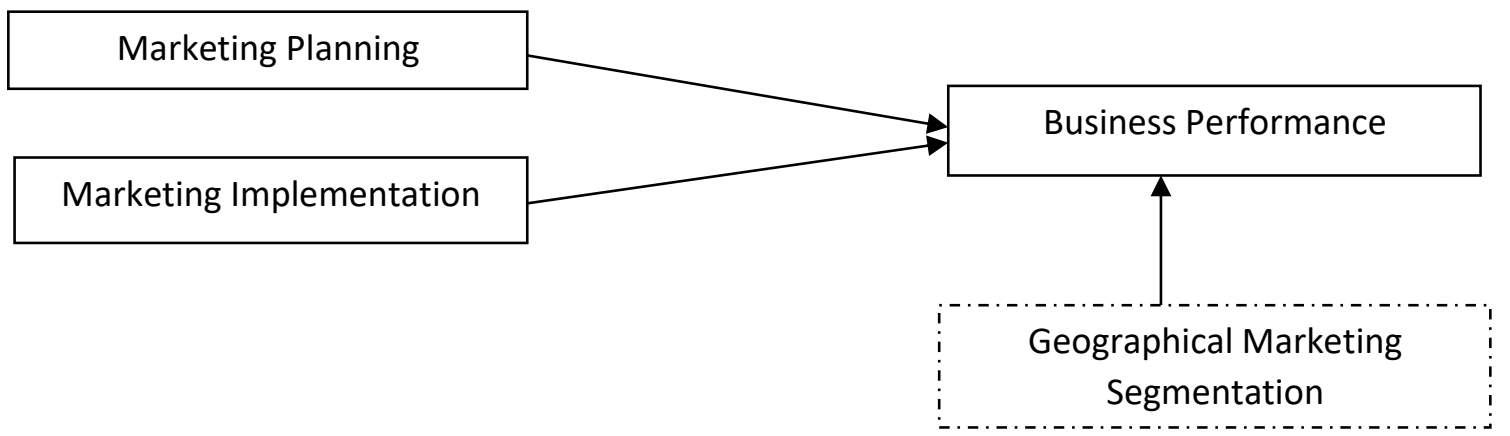

Figure 2: Conceptual Framework for Business Performance

Therefore, based on the RBV theory and past literatures, the following hypotheses were developed:

H1 Marketing planning capability has a positive relationship with business performance.

H2 Marketing implementation capability has a positive relationship with business performance.

H3 There is a significant difference between geographical marketing segmentation and business performance.

$\mathrm{H} 3 \mathrm{a}$ There is a significant difference between local market segmentation and business performance

$\mathrm{H} 3 \mathrm{~b}$ There is a significant difference between regional market segmentation and business performance

$\mathrm{H} 3 \mathrm{c}$ There is a significant difference between national market segmentation and business performance

$\mathrm{H} 3 \mathrm{~d}$ There is a significant difference between international market segmentation and business performance

\section{Methodology}

Based on the framework in Figure 2, there are two variables (marketing planning capabilities and marketing implementation capabilities) that are used to assess the SMEs business performance. Basically, the instrument for this study contained various questions related to the marketing management capabilities namely marketing planning and marketing implementation that contributed to the SMEs' business performance. All items were measured on a ten-point Likert scale which ranged from (1) "Strongly Disagree "and (10) "Strongly Agree". The questionnaire was divided into four sections as follows: 7 questions related to profiles of respondents, 5 questions related to the business performance, 6 questions on marketing planning capabilities and 5 questions for marketing implementation capabilities. The study population consisted of SMEs in East Coast Malaysia (i.e. Kelantan, Pahang and Terengganu). Based on the Economic Census in 2011, the population of this study, involving a total of 1,624 SMEs, are only engaged in manufacturing operations in East Coast Malaysia (SME Annual Report, 2015). According to Krejcie and Morgan (1970), based on that population, 310 firms are sufficient to be used as a sample in this study by using double stage 
of sampling technique namely quota sampling (three states in East Coast Malaysia) and then purposive sampling (fashion business).

Data were collected by using a well-structured and self-administered questionnaire with questions in pre-arranged order. The questionnaire items were developed by the researchers to suit this study. The questionnaire was sectioned into 4 main areas. Section A dealt with the respondent's identity and company's identity which included respondents' general information such as gender, race, age, education level, family background, marketing area and others. Section B represented the dependent variable which was the business performance. Section $C$ touched on the first independent variable which was marketing planning capabilities. Lastly, Section D focused on the marketing implementation capabilities. All items in section B until D were measured on a ten-point Likert Scale ranging from 1Strongly Disagree to 10 -Strongly Disagree. To ensure sufficient data gathered accordingly, the researchers met with respondents who were in their shop and booth. The average time spent by each respondent was approximately 30 to 45 minutes. A total of 350 questionnaires were distributed and 325 (92.8percent) were returned. However, 42 sets were discarded due to incomplete data, resulting in merely 283 usable responses.

\section{Results}

All values yield an alpha coefficient that surpasses the values of 0.70 suggested by (Hair et al., 2006). Reliability estimates (Cronbach's Alpha) for the construct's dimension are as follows: business performance (0.948) consists of 5 items, marketing planning capabilities (0.953) made up of 6 items and marketing implementation capabilities (0.954) contains 5 items, which all suggesting a high degree of reliability.

\section{Frequency Distribution}

The summary of the demographic compositions of the respondents are shown in Table 1 . The participants in this study are predominantly females (73.9 percent) and the majority of the respondents were Malays (92.6 percent). The respondents mainly aged below 25 years old (35.3 percent). Most of them are managers ( 52.7 percent) and are not from entrepreneurial family ( 56.9 percent). The majority of respondents have business experience between 3 to 5 years (51.2 percent). In terms of marketing territories, majority respondents sell their products in the local market (63.3 percent). 
Table 1: SMEs Profile

\begin{tabular}{|c|c|c|c|c|c|c|}
\hline Profile & Qty & $\%$ & \multirow{2}{*}{$\begin{array}{l}\text { Profile } \\
\text { Background }\end{array}$} & \multicolumn{2}{|c|}{ Qty } & \multirow[t]{2}{*}{$\%$} \\
\hline Gender & & & & & & \\
\hline Male & 74 & 26.1 & Entrepreneurs & & 122 & 43.1 \\
\hline Female & 209 & 73.9 & $\begin{array}{l}\text { Not an } \\
\text { entrepreneur }\end{array}$ & & 161 & 56.9 \\
\hline Race & & & Experience & & & \\
\hline Malay & 262 & 92.6 & 3-5 Years & & 145 & 51.2 \\
\hline Chinese & 16 & 5.7 & 6-10 Years & & 76 & 26.9 \\
\hline Indian & 5 & 1.8 & $>10$ Years & & 62 & 21.9 \\
\hline Age & & & Geographical & & & \\
\hline$<=25$ years & 100 & 35.3 & Marketing Area & Yes & 179 & 63.3 \\
\hline 26-30 Years & 54 & 19.1 & Local market & No & 104 & 36.7 \\
\hline 31-35 Years & 49 & 17.3 & Regional Markets & Yes & 82 & 29.0 \\
\hline $36-40$ Years & 22 & 7.8 & (East Coast Malaysia) & No & 201 & 71.0 \\
\hline 41-45 Years & 30 & 10.6 & & Yes & 19 & 6.7 \\
\hline$>=46$ years & 28 & 9.9 & National Market & No & 264 & 93.3 \\
\hline \multicolumn{7}{|l|}{ Position } \\
\hline Owner & 40 & 14.1 & & & & \\
\hline Manager & 149 & 52.7 & & & & \\
\hline Owner \& Manager & 94 & 33.2 & & & & \\
\hline
\end{tabular}

\section{Correlation among Variables}

The result of Pearson Correlation (Table 2) revealed that there is a positive significant correlation between SMEs business performance in fashion industries and marketing management capabilities that consists of marketing planning capabilities and marketing implementation capabilities $(r=0.756$ and 0.774$)$. Table 2 also indicates the mean value of all the constructs was more than 7 . Hence all the variables were deemed acceptable. The business performance had the highest mean value 7.734 with standard deviation of 1.660 , then marketing planning had mean value 7.707 with standard deviation 1.553 and marketing implementation had mean value 7.656 with standard deviation of 1.597 . These values indicate that the respondents agreed with all the statements on business performance, marketing planning capabilities and marketing implementation capabilities.

Table 2: Correlations among variables

\begin{tabular}{lrrr}
\hline & BP & MPC & MIC \\
\hline Business Performance (BP) & 1.000 & & \\
Marketing Planning Capabilities (MPC) & $0.756^{* *}$ & 1.000 & \\
Marketing Implementation Capabilities & $0.774^{* *}$ & 0.896 & 1.000 \\
(MIC) & 7.734 & 7.707 & 7.656 \\
Mean & 1.660 & 1.553 & 1.597 \\
SD & & \\
\hline${ }^{*}$ Correlation is significant at the 0.01 level (two-tailed) & & \\
\hline
\end{tabular}




\section{Regression Analysis among Variables}

Multiple linear regression analysis was used to develop a model for predicting marketing management capabilities that consists of two dimensions namely marketing planning and marketing implementation with business performance among SMEs in fashion industries (Table 3). The result shows that marketing management capabilities consisting of marketing planning and marketing implementation contribute significantly ( $F=227.894 ; p=0.000)$ predicting 61.9 percent of the variations in business performance among SME, specifically Malaysian fashion industries. Therefore, those dimensions predict significant change in business performance of fashion industries. Furthermore, there is a significant relationship between marketing planning $(t=3.818 ; p=0.000)$, marketing implementation $(t=5.896, p=$ 0.000 ) and SME business performance in fashion industries at 5 percent at significant level. Thus, there is statistically significant evidence to support $\mathrm{H} 1$ and $\mathrm{H} 2$. Moreover, there are no multicollinearity issues in this study, which is the tolerance values less than 1 and VIF value less than 10 (Pallant, 2007).

Table 3: Summary of Regression Analysis

\begin{tabular}{|c|c|c|c|c|c|c|c|c|c|}
\hline \multicolumn{2}{|c|}{ Summary } & \multicolumn{2}{|c|}{ Anova } & \multirow[b]{2}{*}{ Dimensions } & \multirow[b]{2}{*}{ B } & \multirow[b]{2}{*}{$\mathbf{t}$} & \multirow[b]{2}{*}{$\begin{array}{c}\text { p- } \\
\text { value }\end{array}$} & \multicolumn{2}{|c|}{$\begin{array}{c}\text { Collinearity } \\
\text { Statistics }\end{array}$} \\
\hline $\mathbf{R}$ & $\mathbf{R}^{2}$ & $\mathbf{F}$ & sig & & & & & $\begin{array}{c}\text { Tolera } \\
\text { nce }\end{array}$ & VIF \\
\hline \multirow[t]{2}{*}{$.787^{\mathrm{a}}$} & 0.619 & 227.894 & $.000^{\mathrm{b}}$ & $\begin{array}{l}\text { Marketing } \\
\text { Planning }\end{array}$ & 0.339 & 3.818 & 0.000 & 0.197 & 5.081 \\
\hline & & & & $\begin{array}{l}\text { Marketing } \\
\text { Implementation }\end{array}$ & 0.509 & 5.896 & 0.000 & 0.197 & 5.081 \\
\hline
\end{tabular}

a. Dependent Variable: Business Performance

\section{Analysis of Differences}

Based on the distribution of samples, the analysis of differences between geographical marketing segmentation and business performance is conducted by using several techniques that satisfy the basic statistical requirement. Among the techniques used are: T-test and Mann-Whitney U. Table 4 shows that respondents' concentrated regional markets (East Coast Malaysia) are significantly different with not concentrated Regional Markets (East Coast Malaysia) on business performance, $(p<0.05 ; 0.018)$. Referring to the two groups' means indicates that the business performance among concentrated entrepreneurs (8.088) is significantly higher than the non-concentrated ones (7.589). It is noted that for respondents that focused on the National market as geographical marketing segmentation and business performance, there is statistically significant difference between respondents not focused on the national market $(p<0.05,0.026)$. However, respondents concentrated on the local market do not differ significantly from the not concentrated local market $(p>0.05,0.064)$ on business performance. Furthermore, the difference between respondents penetrating and not penetrating the international market with business performance $(p>0.05,0.443)$ is not statistically significant. Therefore, there is a statistical significance to support hypothesis $\mathrm{H} 3 \mathrm{~b}$ and $\mathrm{H} 3 \mathrm{c}$. However, hypothesis $\mathrm{H} 3 \mathrm{a}$ and $\mathrm{H} 3 \mathrm{~d}$ were not supported. 
Table 4: T-test for testing differences between Geographical Marketing Segmentation and Business Performance

\begin{tabular}{lrrr}
\hline \multicolumn{1}{c}{ Variable } & Qty & $\begin{array}{l}\text { Mean } \\
\text { Value }\end{array}$ & Sig. Value \\
\hline Local Market & & & \\
Yes & 179 & 7.597 & 0.064 \\
No & 104 & 7.970 & \\
Regional Markets (East Coast Malaysia) & & & \\
Yes & 82 & 8.088 & 0.018 \\
No & 201 & 7.589 & \\
National Market & & & \\
Yes & 19 & 6.884 & 0.026 \\
No & 264 & 7.795 & \\
International Market & & & \\
Yes & 12 & 8.267 & 0.443 \\
No & 271 & 7.710 & \\
\hline
\end{tabular}

Overall Findings of the Study

This study analyses the two (2) theorized relationships ( $\mathrm{H} 1$ to $\mathrm{H} 2$ ) and four hypothesized differences ( $\mathrm{H} 3 \mathrm{a}$ to $\mathrm{H} 3 \mathrm{~d}$ ). The data was examined using SPSS software program SPSS version 25 and by study to determine the importance of the path for each of the hypothesized paths. The findings indicated that marketing management capabilities (marketing planning and marketing implementation) had a significant relationship with business performance for SMEs in East Coast Malaysia. In fact, marketing management capabilities play an important factor in improving their business performance. Consequently, the hypotheses of relationship H1 and $\mathrm{H} 2$ were supported. Finally, the findings of differences revealed that as follows: 1) the SMEs' penetrated regional market significantly different from SMEs' not penetrated regional market on business performance; 2 ) the SME's entered national market are significantly difference from not entered regional market on business performance; 3 ) the SMEs' that only focused local market does not differ significantly from international market on the business performance. Therefore, it supported hypotheses $\mathrm{H} 3 \mathrm{~b}$ and $\mathrm{H} 3 \mathrm{c}$, whereas $\mathrm{H} 3 \mathrm{a}$ and $\mathrm{H} 3 \mathrm{~d}$ were not supported. Table 5 exhibited the overall findings of this study. 
Table 5: Overall Findings of the Study

\begin{tabular}{|c|c|c|c|c|c|}
\hline H & Perception & Analysis & Sig. & Result & \\
\hline $\mathrm{H} 1$ & $\begin{array}{l}\text { Positive } \\
\text { between } \\
\text { planning capabilities anship } \\
\text { business performance }\end{array}$ & Regression & $\begin{array}{c}p= \\
0.000\end{array}$ & $\begin{array}{l}\text { Significant } \\
\text { relationship }\end{array}$ & Supported \\
\hline $\mathrm{H} 2$ & $\begin{array}{l}\text { Positive relationship } \\
\text { between } \\
\text { planning capabilities and } \\
\text { business performance }\end{array}$ & Regression & $\begin{array}{c}p= \\
0.000\end{array}$ & $\begin{array}{l}\text { Significant } \\
\text { relationship }\end{array}$ & Supported \\
\hline H3a & $\begin{array}{l}\text { The significant difference } \\
\text { between local market and } \\
\text { business performance }\end{array}$ & t-test & $\begin{array}{c}p= \\
0.064\end{array}$ & $\begin{array}{l}\text { No significant } \\
\text { difference }\end{array}$ & $\begin{array}{c}\text { Not } \\
\text { supported }\end{array}$ \\
\hline $\mathrm{H} 3 \mathrm{~b}$ & $\begin{array}{l}\text { The significant difference } \\
\text { between regional market } \\
\text { and business performance }\end{array}$ & t-test & $\begin{array}{c}p= \\
0.018\end{array}$ & $\begin{array}{l}\text { Significant } \\
\text { difference }\end{array}$ & Supported \\
\hline $\mathrm{H} 3 \mathrm{C}$ & $\begin{array}{l}\text { The significant difference } \\
\text { between national market } \\
\text { and business performance }\end{array}$ & $\begin{array}{c}\text { Man- } \\
\text { Whitney U }\end{array}$ & $\begin{array}{c}p= \\
0.026\end{array}$ & $\begin{array}{l}\text { Significant } \\
\text { difference }\end{array}$ & Supported \\
\hline H3d & $\begin{array}{l}\text { The significant difference } \\
\text { between international } \\
\text { market and business } \\
\text { performance }\end{array}$ & $\begin{array}{c}\text { Man- } \\
\text { Whitney U }\end{array}$ & $\begin{array}{c}p= \\
0.443\end{array}$ & $\begin{array}{c}\text { No significance } \\
\text { difference }\end{array}$ & $\begin{array}{c}\text { Not } \\
\text { supported }\end{array}$ \\
\hline
\end{tabular}

\section{Discussion}

The purpose of this study is to examine the positive relationship of marketing management capabilities dimensions; namely marketing planning and marketing implementation with SMEs business performance in the fashion industry in Malaysia. Looking at the arguments supporting the marketing research adopted, this study hypothesized that the culture of marketing planning capabilities and marketing implementation capabilities executed in the fashion industry of SMEs will provide an opportunity to increase marketing management capabilities and consequently will increase business performance. The results of this study confirm that all dimensions of marketing management capabilities are important drivers in increasing business performance. The findings are similar to Takata (2016) that emphasize the role of marketing management capabilities in increasing business performance.

Furthermore, the result supports the theoretical assumption of RBV that marketing management capabilities are the drivers influencing the SMEs business performance. The finding of this study confirms that marketing planning capabilities and marketing implementation capabilities have a significant relationship with business performance for SMEs in East Coast Malaysia, thus, $\mathrm{H} 1$ and $\mathrm{H} 2$ are supported. These findings are in line with Krasnikov et al (2009) for marketing planning capabilities and Vohies and Morgan (2005); White et al (2003) for marketing implementation capabilities. In fact, the evidence generated from the regression analysis clearly indicated that 61.9 percent variation in the business performance among SMEs in East Coast Malaysia can be explained by variation in overall independent variables namely marketing planning capabilities and marketing implementation capabilities. As noted in Table 3, the strength of correlation value of 0.774 and significant $p$ - 
value at 0.000 , clearly strengthened the importance of marketing management capabilities in relation to the SMEs business performance. The relatively significant contribution of marketing management capabilities was further explained by looking at the Beta score of the analysis (Table 3). From the result of Beta coefficient, the value for the second independent variable, that is marketing implementation capabilities, was 0.509 , at $p<0.05$ which explained that a percentage increase of 50.9 percent in marketing implementation capabilities will increase the SMEs business performance.

Moreover, understanding the differences on the geographical marketing segmentation will provide an interesting database for an informed decision. The findings derived from this analysis clearly demonstrated that there was statistically significant difference in the two (2) types of geographical marketing segmentation which is regional marketing segmentation and national marketing segmentation with business performance. However, local market segmentation and international market segmentation revealed no significant differences with business performance. Thus, with this evidence, it will be much easier for SMEs owners, Ministry of International Trade and Industry (MITI) and Ministry of Rural Development to lay out the vision and strategies in improving the business performance and sustaining the firm's competitive advantage both at local and international market.

\section{Conclusions}

As a conclusion, this study showed that marketing implementation capabilities is the most important driver in influencing SMEs business performance. Although SMEs owners were successful in developing excellent marketing planning capabilities; but if their marketing implementation capabilities failed, it will deter in improving the business performance of the firm. In other words, planning without implementation will not increase the firm's business performance. The COVID-19 pandemic has impacted many entrepreneurs, especially SMEs owners, disrupting the economy and business trade both at local and international as well as changing consumer behaviour. The ultimate goal for SMEs owners during the COVID-19 pandemic is to ensure that even though business operations are disrupted, business performance must be sustained for operational resilience. The current COVID-19 crisis situation is an opportunity for SMEs owners to re-evaluate their business model by adopting flexible and agile marketing management capabilities to accommodate today's uncertain environment.

Regarding geographical marketing segmentation, the current pandemic crisis is also an opportunity for SMEs owner to move towards a profound, systemic transformation and sustainable business operations. Adopting online marketing penetration to accelerate demand and creating digital interactions globally are amongst the new enduring strategies for marketing management capabilities to increase business performance. Availability of customer profiling and analytics through digital platforms will assist SMEs owners to track shifts in demand across geographies, categories, channels, value and lifestyle segments.

The environmental and social implications of clothing production and consumption, are highly relevant to integrate the targets of the United Nations 17 Sustainable Development Goals (SDGs) in the fashion industry. The aim of SDGs commitment is to ensure the fashion industry gives positive impacts and is sustainable for humankind and the ecosystem. If SMEs owners in the fashion industry work to adopt the SDGs, then the fashion industry can become a place that contributes to global equality, biodiversity, and overall well-being (Jessy, 2021). Thus, for SMEs owners to uphold those SDGs, business model transformation in engaging with 
consumers for better consumption habits need to be executed by developing sustainable design strategies, promoting the use of sustainable technologies and appropriate resource management throughout the fashion industry supply chain (Audrey, 2019).

Government should also educate SMEs on using more technology in order to keep pace with the times and innovate a new and timely demanded product to meet a market requirement (Yuena, 2021). Undoubtedly, technology helps business to expand market share and search for new idea for business growth (Nurulhasanah et. al, 2016). Yet, this is where the geographical expansion leads to a problem (Pirich, Knuckey \& Campbell, 2001; Cull et. al., 2006) on how to reach the customers in distance. Hence, technology comes in with emerging economy booster through the social networking (Littunen, 2010; Naude, Zaefarian, Tavani, Neghabi \& Zaefarian, 2014; Choban, Oskenbayev, Aman \& Youssuf, 2015), computerized record (Saad \& Mazzaro, 2010; Osotimehin et al., 2012) and online marketing (Reiss, 2006; Littunen, 2010; Lee, Park \& Shin, 2012 ) will further assists SMEs to increase business performance during the pandemic.

Although the government has supported SMEs, it shows government still have room to bring more education and subsidy to local business so that SME able to improve innovation level as SME is the economy backbone in Malaysia. Moreover, as most of the Malaysian SMEs are local business or family business with practicing traditional business concept. From the observation, it is important to upgrade their poorly developed industrial and technological infrastructure. Government needs to promote the importance of innovation will affect the business. SMEs can be more innovative through learning, knowledge sharing and upgrading skills. Improving innovation performance is a stage-by-stage approach institutionalised across a whole firm. The government or community needs to understand the different perspective between rural and urban SMEs before implementing new policy or education, such as the capability level and innovativeness level. In the lens of COVID-19, it is vital for the Malaysian government to comprehends on the existing Malaysian government initiatives, which is Pakej Rangsangan Ekonomi Rakyat (PRIHATIN) by extending the initiatives for sustainable business operations and monitoring the financial support given to ensure resiliency of SMEs business performance. Furthermore, suggested collaboration between the Ministry of International Trade and Industry (MITI) and the Ministry of Rural Development in providing a digital platform for SMEs owners to be competitive at both local and international market will have a devastating impact on the business performance of SMEs that are involved in the fashion industry in Malaysia.

The limitations of this study could be addressed in future research. Firstly, this study only managed to collect data from 283 SMEs owners that were involved in the fashion industry in East Coast Malaysia. The findings can only be generalized for the selected respondents; and not for all SMEs in East Coast Malaysia. Future research should focus on increasing the respondent sample size using different means of communication, such as through online survey platforms; and identify the population of SMEs in the fashion industry in other parts of Malaysia in order to define this phenomenon in a wider way. Secondly, it could be interesting if more considerations of other variables such as situational factors, responsiveness to the market, customer orientation, competitor's orientation, innovation and marketing as well as specialized marketing capabilities to be included in future research. Thirdly, future research could also conduct qualitative research that involves in depth interview sessions with SMEs owners to gain further understanding on the challenges in sustaining business performance and barriers in penetrating global markets in the fashion 
industry during this pandemic crisis. Finally, from a geographical marketing segmentation perspective, future research could carry out a comparison study with samples from other countries to gauge a wider perspective in the issues of SMEs in the fashion industry around the world.

\section{References}

Audrey, S. (2020). How the United Nations' SDGs Relate to the Fashion Industry. Remake. https://remake.world/stories/news/how-the-united-nations-sdgs-relate-to-thefashion-industry/

Anh, N. T. (2021). Sustainable Marketing in the Fashion Industry. A study of consumer behavior towards sustainability in the fashion industry to optimize sustainable marketing in Europe during and post Covid-19 https://aaltodoc.aalto.fi/handle/123456789/21758

Bank Negara Malaysia (2005). https://www.bnm.gov.my/documents/20124/1330951/chap_2.pdf

Barney, J. (1991), "Firm resources and sustained competitive advantage", Journal of Management, 17 (1), pp. 99-120.

BCG. (2019). Luxury Market Trends-Digital \& Experiential Luxury. Available online:http://mediapublications.bcg.com/france/TrueLuxury\%20Global\%20Consumer \%20Insight\% 202019\% 20-\%20Plenary\%20-\%20vMedia.pdf (accessed on 29 January 2021).

Bhatti, A., Akram, H., Basit, H. M., Khan, A. U., Raza, S. M. (2020). E-Commerce Trends during COVID-19 Pandemic. Int. J. Futur. Gener. Commun. Netw.13, 1449-1452.

Blackburn, R., Brush, C., \& Blank, A. (2009), "Understanding the challenges to growth in entrepreneurial firms: cases from the UK and USA", paper presented at the XXIII RENT Conference, Budapest, 19-20 November.

Cizmar, S., Weber, S. (2000) Marketing effectiveness of the hotel industry in Croatia. International Journal of Hospitality Management, 19(3), 227-240.

Chang, W., Park, E. J., \& Chaiy, S. (2010), How does CRM technology transform into organizational performance? A mediating role of marketing capability. Journal of Business Research, 63, 849-855.

Cho, H., \& Pucik, V. (2005). Relationship between innovativeness, quality, growth, profitability, and market value. Strategic Management Journal, 26(6), 555-575. doi: 10.1002/smj.461

Choban, Oskenbayev, A., \& Youssuf. (2015). Role of Social Networks on Entrepreneurship in Kazakhstan. Proceedings of 8th Asia-Pacific Business Research Conference.

Cull, R., Davis, L. E., Lamoreaux, N. R., \& Rosenthal, J. L. (2006). Historical financing of smalland medium-size enterprises. Journal of Banking \& Finance, 30 (11), 3017-3042.

Davidsson, P., Steffens, P. and Fitzsimmons, J. (2009), "Growing profitable or growing from profits: putting the horse in front of the cart?", Journal of Business Venturing, Vol. 24, pp. 388-406.

Day, G. S. (1994), The Capabilities of Market-Driven Organizations. Journal of Marketing, 58(4), 37-52.

Debicki, B. J., Randolph, R. V. D. G., \& Sobczak, M. (2017). Socioemotional Wealth and Family Firm Performance: A Stakeholder Approach. Journal of Managerial Issues. 29(1).; pp 82111 
Dellarrt, B. G. C. (2018) 'The consumer production journey: marketing to consumers as coproducers in the sharing economy.' Cross Mark [Online]. 47: 238 - 254.

Deloitte. (2020). Global Power of Luxury Goods 2019. Available online: https://www2.deloitte.com/it/it/pages/about-deloitte/forms/deloitte-global-powersluxury-goods-2019---form-registrazione.html (accessed on 29 January 2021).

Galbreath, J., \& Galvin, P. (2004), "Which resources matter? A fine-grained test of the resource-based view of the firm", Academy of Management Proceedings, New Orleans.

Gao, G. Y., Zhou, K. Z., \& Yim, C. K., \& Bennett (2007). On what should firms focus in transitional economies? A study of the contingent value of strategic orientations in China. International Journal of Research in Marketing, 24(1), 3-15. doi:10.1016/j.ijresmar.2006.09.004

Gazzola, P., Pavione, E., Pezzetti, R., \& Grechi, D. (2020). Trends in the Fashion Industry. The Perception of Sustainability and Circular Economy: A Gender/Generation Quantitative Approach. Sustainability, 12(7), 2809.

GIER. (2020). State of The Global Islamic Economy Report 2019/20: Driving the Islamic Economy Revolution 4.0 https://www.salaamgateway.com/specialcoverage/SGIE19-20

Hendra, S., Raden, A. S., Ika, B. S., Arnis, B. S., (2021). The Effect of Management Capability on The Performance of Batik Smes: The Role of Sustainable Innovation Mediation And Business Strategy. Palarch's Journal of Archaeology of Egypt/Egyptology 18(7). ISSN 1567-214x

Jaakkola, M., Möller, K., Parvinen, P., Evanschitzky, H., \& Mühlbacher, H. (2010). Strategic marketing and business performance: A study in three European 'engineering countries. Industrial Marketing Management, 39(8), 1300-1310.

Jessy, H. (2020). New Intelligent Luxury Magazine. Luxiders Magazine https://luxiders.com/sustainable-trends/

Kotler, P. (2004), "A three-part plan for upgrading your marketing department for new challenges", Strategy \& Leadership, 32(5), pp. 4-

9. https://doi.org/10.1108/10878570410557615

Kotler, P., \& Keller, K. (2009), Marketing Management (1Ed.). New Jersey: Pearson International Edition.

Krasnikov, A., \& Jayachandran, S. (2008). The relative impact of marketing, research-and development, and operations capabilities on firm performance. Journal of Marketing, 72(4), 1-11.

Krasnikov, A., Jayachandran, S., \& Kumar, V. (2009), The Impact of Customer Relationship Management Implementation on Cost and Profit Efficiencies: Evidence from the U.S. Commercial Banking Industry. Journal of Marketing, 73(6), 61-77.

Krejcie, R., \& Morgan, D. (1970). Determining sample size for research activities. Educational and Psychological Measurement, 30, 607-610

Krinstandl, G., \& Bontis, N. (2007). Constructing a definition for intangibles using the resourcebased view of the firm. Management Decision; 45(9); pp: 1501-1524: DOI 10.1108/00251740710828744

Lee, Y.-K., Kim, S.-H., Seo, M.-K., \& Hight, S. K. (2015). Market orientation and business performance: Evidence from franchising industry. International Journal of Hospitality Management, 44, 28-37. doi:10.1016/j.ijhm.2014.09.008

Lee, Y., Shin, J., \& Park, Y. (2012). The changing pattern of SME's innovativeness through business model globalization. Technological Forecasting \& Social Change, 79, 832-842. 
Littunen, M. V. H. (2010). Types of innovation, sources of information and performance in entrepreneurial SMEs. European Journal of Innovation Management, 13 (2), 128 - 154.

Mazzarol, T., Reboud, S., \& Soutar, G. (2009), "Strategic planning in growth orientated firms", International Journal of Entrepreneurial Behaviour \& Research, Vol. 15 Nos 3/4, pp. 32045.

McKinsey \& Company. (2020). The State of Fashion 2021 https://www.mckinsey.com/ /media/McKinsey/Industries/Retail/Our\%20Insights/Sta te\%20of\%20fashion/2021/The-State-of-Fashion-2021-vF.pdf

Morgan, N. A. (2012). Marketing and business performance. Journal of the Academy of Marketing Science, 40(1), 102-119.

Morgan, N. A., Vorhies, D. W., \& Mason, C. H. (2009), Market Orientation, Marketing Capabilities and Firm Performance. Strategic Management Journal, 30(8), 909 -920.

Naude, P., Zaefarian, G., Tavani, Z. N., Neghabi, S., \& Zaefarian, R. (2014). The influence of network effects on SME performance. Industrial Marketing Management, 43, 630-641.

Ngo, L. V., \& O'Cass, A. (2012). Performance implications of market orientation, marketing resources, and marketing capabilities. Journal of Marketing Management, 28(1-2), 173-187.

Nurulhasanah A. R., Zulnaidi Y., Rafisah M. R. (2016), An Overview of Technological Innovation on SME Survival: A Conceptual Paper. Procedia - Social and Behavioral Sciences, 224 (2016) 508 - 515 doi: 10.1016/j.sbspro.2016.05.427

Osotimehin, K. O., Jegede, C. A., Akinlabi, H. B., \& Olajide, O. T. (2012). An Evaluation of the Challenges and Prospects of Micro and Small Scale Enterprises Development in Nigeria. American International Journal of Contemporary Research. 2(4), 175-185.

Pallant, J. (2007). SPSS Survival Manual, McGraw Hill

Pulendran, S., Speed, R., \& Widing, R. E. (2003). Marketing planning, market orientation and business performance. European Journal of Marketing Vol. 37 No. 3/4, 2003 pp. 476497 q MCB UP Limited 0309-0566 DOI 10.1108/03090560310459050

Pirich, A., Knuckey, S., \& Campbell, J. (2001). An Interface between Entrepreneurship \& Innovation. Denmark, Aalborg University, 10-11.

Razak, N. A., Isa, K., \& Latiff, A. A. (2020). The Impact of COVID-19 Outbreak on SMEs in Malaysia. 36th IBIMA Conference: 4-5 November 2020, Granada, Spain. ISBN: 978-09998551-5-7

Reiss, F. (2006). Why Small Businesses Fail. Retrieved March 10, 2015 from http://www.publishinggame.com/art_whysmallbusinessesfail.htm

Richbell, S., Watts, H., \& Wardle, P. (2006), "Owner-managers and business planning in the small firm", International Small Business Journal, Vol. 24 No. 5, pp. 496-514.

Robert, A. B., Mark, H., Thomas, W. (2013) Small business performance: business, strategy and owner-manager characteristics. Journal of Small Business and Enterprise Development. Vol. 20 No. 1, 2013 pp. 8-27q Emerald Group Publishing Limited 14626004 DOI 10.1108/14626001311298394

Saad, S., \& Mazzarol, T. (2010). The Impact of Leadership on Organisational Innovation Performance among Malaysia's Multimedia Super Corridor (MSC) SME (November 29, 2010). International Conference on Applied Business Research (ICABR), 29 November to 3 December 2010, Ras Al Khaimah UAE. Available at SSRN:

http://ssrn.com/abstract=2124708 
Salter, F. S., Hult, M. T. G., \& Olsen, M. E. (2010), Factors influencing the relative importance of marketing strategy creativity and marketing strategy implementation effectiveness. Industrial Marketing Management, 39, 551-559.

Slotegraaf, J. R., \& Dickson, R. P. (2004), The Paradox of a Marketing Planning Capability. Journal of the Academy of Marketing Science, 32(A), 371-385.

Stam, W., Arzlanian, S., \& Elfring, T. (2014). Social capital of entrepreneurs and small firm performance: A meta-analysis of contextual and methodological moderators. Journal of Business Venturing, 29(1), 152-173. doi:10.1016/j.jbusvent.2013.01.002 http://www.emeraldinsight.com/journals.htm?articleid=840661

St-Jean, E., Julien, P.-E., and Audet, J. (2008), "Factors associated with growth change in 'gazelles'”, Journal of Enterprising Culture, Vol. 16 No. 2, pp. 161-88.

Takata, H. (2016), Effects of industry forces, market orientation, and marketing capabilities on business performance: An empirical analysis of Japanese manufacturers from 2009 to 2011. Journal of Business Research (2016), http://dx.doi.org/10.1016/j.jbusres.2016.03.068

Taleghani, M., Gilaninia, S., \& Mousavian, S. J. (2011). The role of relationship marketing in the customer orientation process in the banking industry with focus on loyalty (case study: Banking industry of Iran). International Journal of Business and Social Science, 2(19), Merr

United Nations Conference on Trade and Development. (2020). COVID-19 has changed online shopping forever, survey shows.

https://unctad.org/news/covid-19-has-changed-online-shopping-forever-surveyshows

Vorhies, D. W., \& Morgan, N. A. (2005), Benchmarking Marketing Capabilities for Sustainable Competitive Advantage. Journal of Marketing, 69(1), 80-94.

Vorhies, D. W., Morgan, R. E., \& Autry, C. W. (2009), Product-market strategy and the marketing capabilities of the firm: impact on market effectiveness and cash flow performance. Strategic Management Journal, 30(12), 1310-1334.

Wiklund, J., \& Shepherd, D., (2005). Entrepreneurial orientation and small business performance: A configurational approach. Journal of Business Venturing 20;71-91

World Trade Organization (WTO). (2020). World Trade Statistical Review 2020

White, C. J., Contant, S. J., Echambadi, R. (2003), Marketing Strategy Development Styles, Implementation Capability, and Firm Performance: Investigating the Curvilinear Impact of Multiple Strategy-Making Styles. Marketing Letters, 14(2), 111-124.

Yee, Y, Y., Xiang, P. N. (2021). Enhancing innovation performance of small and medium enterprises in Malaysia. (C) 2021 by the authors; licensee Growing Science, Canada doi: $10.5267 /$ j.msl.2020.10.010 http://www.growingscience.com/msl 